$$
\text { دوماهنامه طبّ جنوب }
$$

ئزوهشكده زيست - يزشكى خليج فارس

دانشخاه علوم بزشكى و خدمات بهداشتى درمانى بوشهر

سال نوزدهم، شماره ه، صفحه

Iran South Med J 2016; 19(5): 809-818

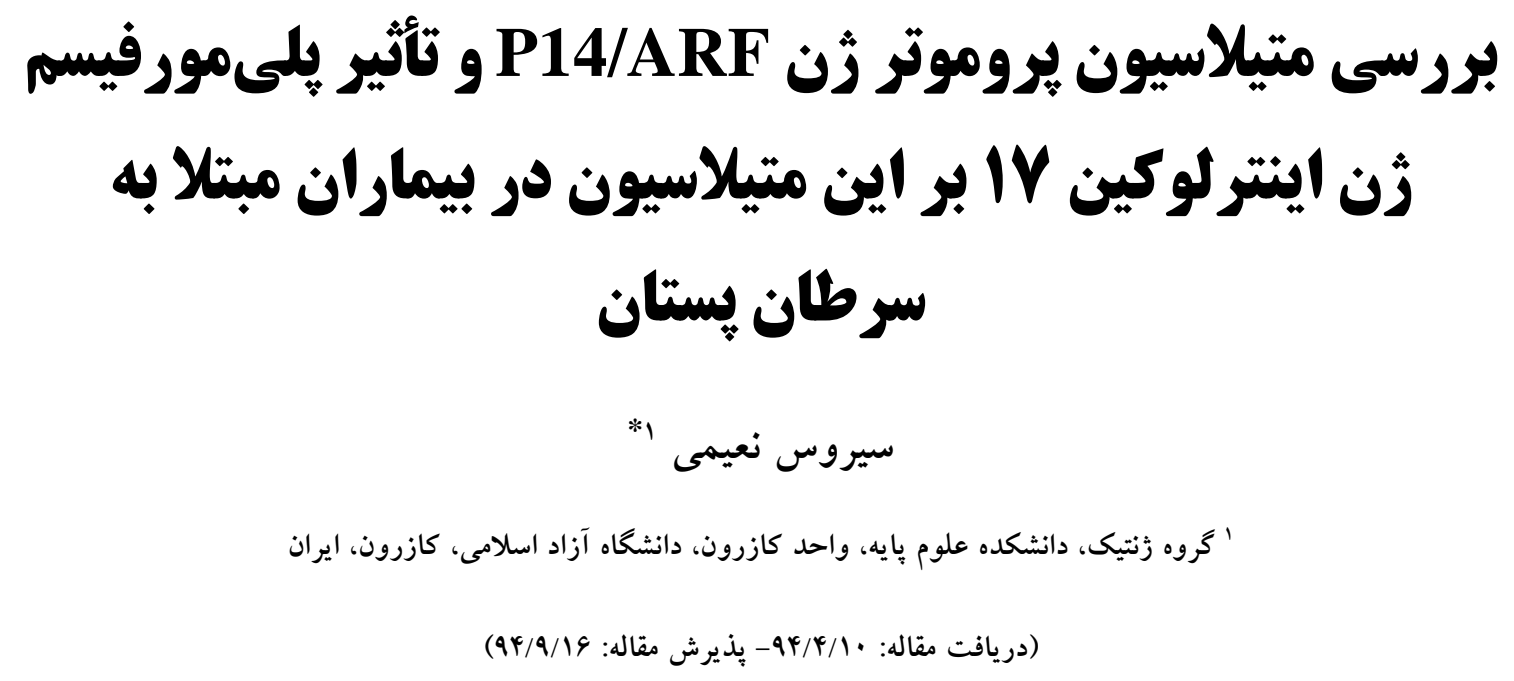

جكيده

زمينه: افزايش متيلاسيون در جزاير CPG، يكى از مكانيسمهاى مهم در خاموش شدن زن مىباشد. در بسيارى از سرطانها، زنهاى

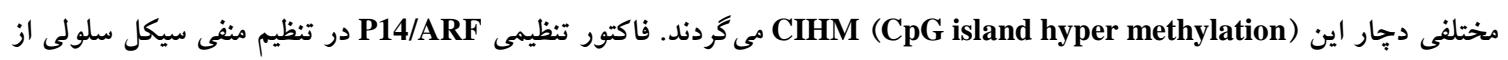

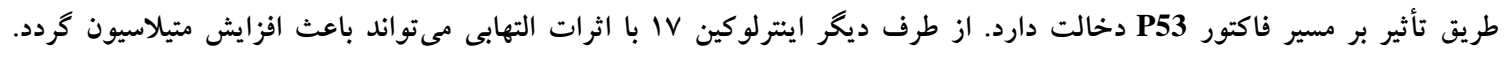

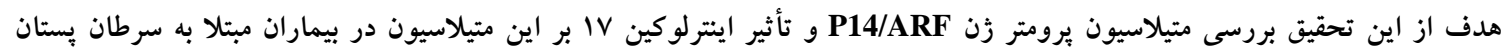
در جنوب كشور ومقايسه آن با افراد سالم مى باشد.

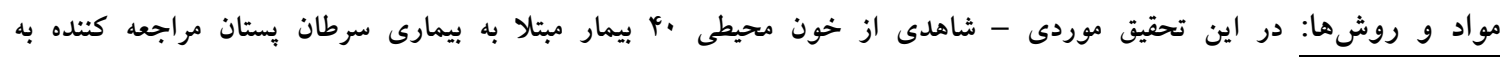

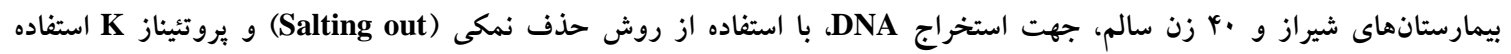

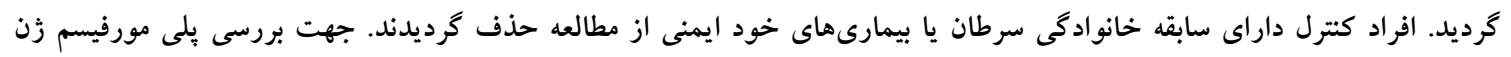

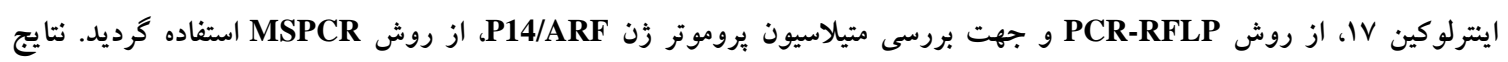

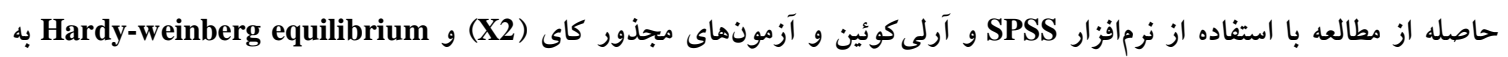

ترتيب مورد مطالعه قرار خرفت.

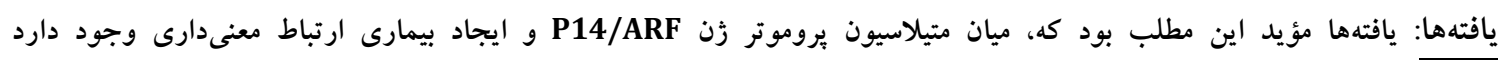

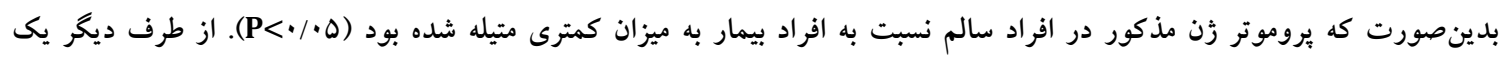

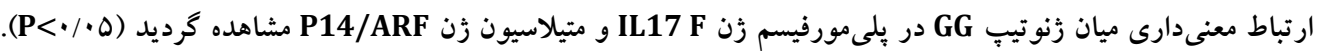

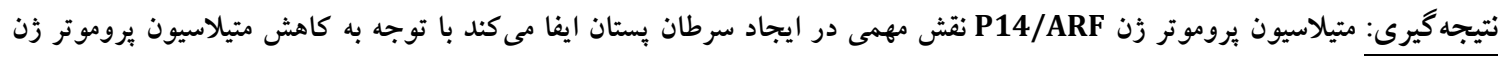

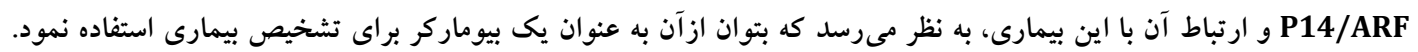

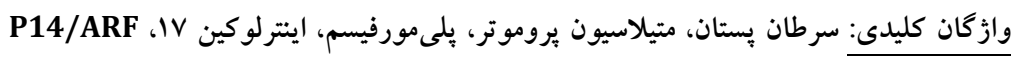


تنظيمى در لوكوس مهار كننده سرطان، يعنى مقدمه

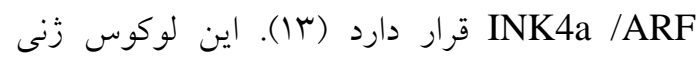
باعث كددهى يروتئينهايى مىشود كه در اصل يك لئ

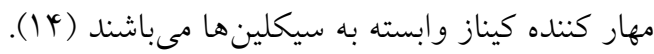
اخر جهه موتاسونهايى كه منجر به غير فعال شدن

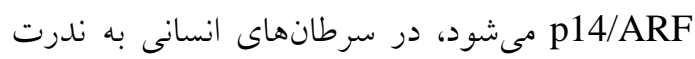

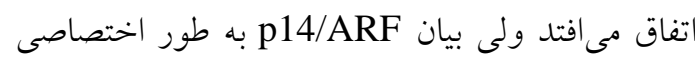
در تومورهاى انسانى تغيير مىيابد (ها) كه اين اتفاق

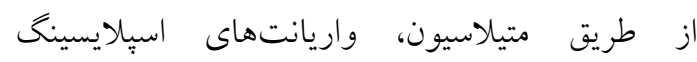
جايگاهها و و فاكتورهاى سرطانزاى Aml-ETo

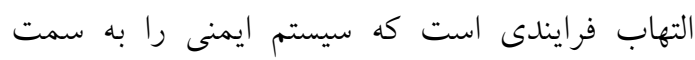
عفونت يا بافتهاى آسيب ديده هدايت مى كند. التهاب مزمن يك نقش مهم در ياتوزنز بيمارىهاى خودايمنى،

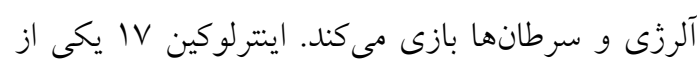

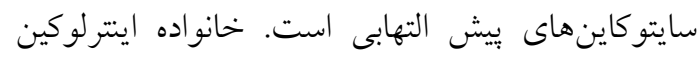
IV متشكل از 9 جزء است، (19-19). كه در اين ميان، اينترلوكين IL-17A و IL-17F بيشتر بررسى شدهاند.

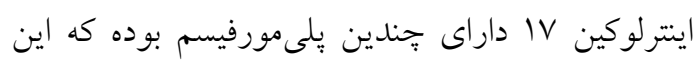

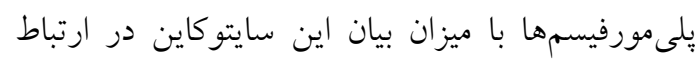

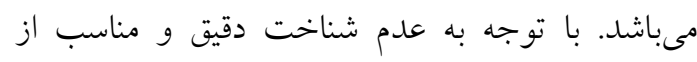

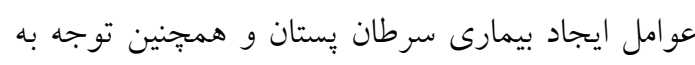

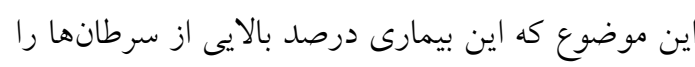

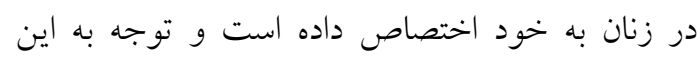
نكته كه يكى از مشكلات اساسى در سرطانها، ناميرا

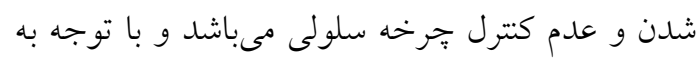

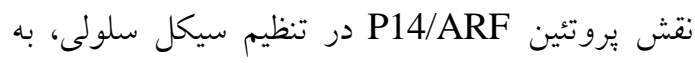
نظر مىرسد كه تغييرات در بيان اين يروتئين مىتواند

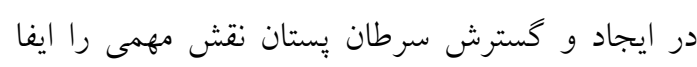
نمايد. لذا هدف از اين تحقيق، بررسى ارتباط ميان

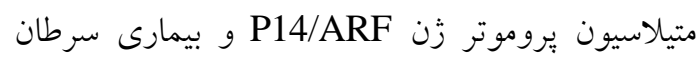

امروزه مكانيسمهاى إبىزنتيكى به عنوان يكى فاكتور مشخص در توسعه سرطان بِستان شناخته مىشوند (1).

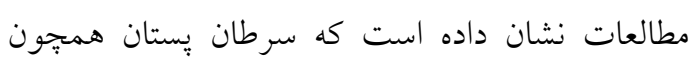

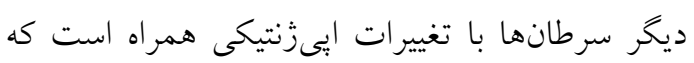
اين تغييرات بدون اينكه تغييرى در توالى اوليه DNA

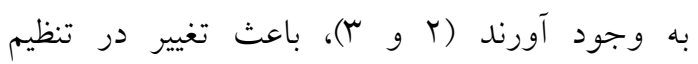
غيرطبيعى فاكتورهاى نسخهبردارى و به دنبال آن تغيير در تكثير سلولى، بقاى سلولى و همجِنين تمايز سلولى

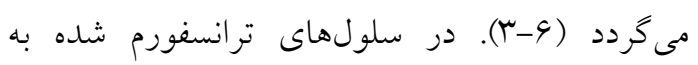
سلولهاى سرطانى، تغييرات ايىزنتيكى در سطح

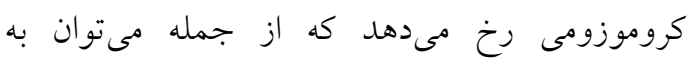
متيلاسيون DNA، تغييرات هيستونى، و تغييرات به دمونه وجود آمده در عملكرد و بيان فاكتورهاى دخيل در

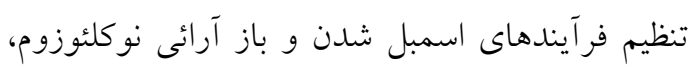

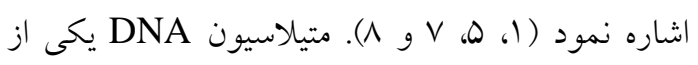

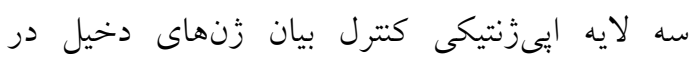

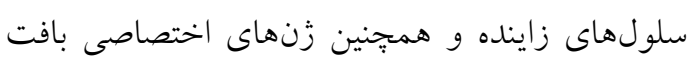

مىباشد (9).

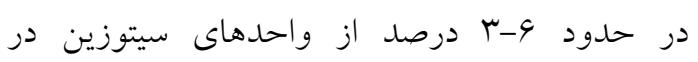
هُتانداران متيله مىباشد. اين متيلاسيون باعث تأثير بر روى بيان زن مى گردد، خصوصاً وقتى كه اين داى بئن

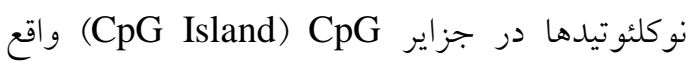
شده باشند. اين جزاير غالباً در نواحى يروموتر زنها واقع شدهاند (r ا-ن (1).

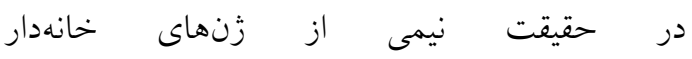

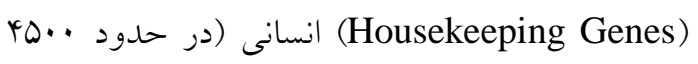
زن)، حاوى جزاير CpG در ناحيه بروموتر خود

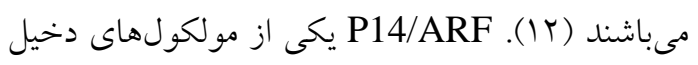
در تنظيم سيكل سلولى است كه منجر به تنظيم منفى سيكل سلولى از طريق مسير P53 مى گردد. اين فاكتور 
شرايط اخلاقى يزشكى رعايت كرديد و از بيماران

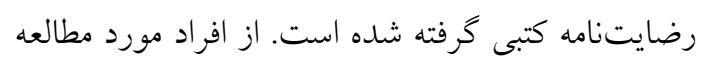
ه سىسى خون سياهرگى گرفته شد و به لولههاى

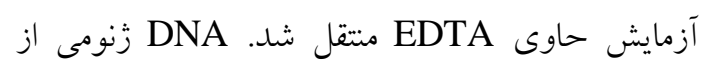

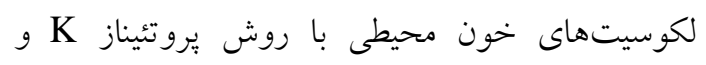

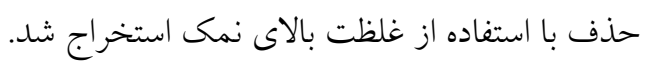

واكنش RFLP-PCR جهت بررسى پلى مورفيسم اينترلوكين وا صل براى تعيين زنوتيڤ زن زين اينتولوكين IV افراد مورد

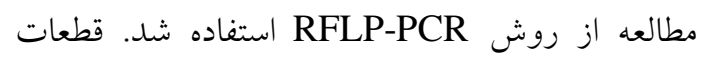
حاوى هر جايگاه با استفاده از يرايمرهاى

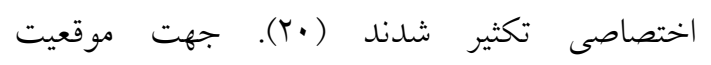
IL-17A G197A ״ستان بوده و از طرف ديخر به بررسى تأثير

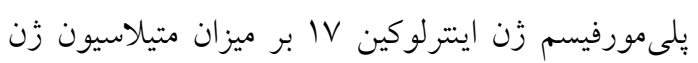
P14/ARF

\section{مواد و روشها - (- ماد} كروه مورد مطالعه شامل •4 نقر مبتلا به سرطان يستان

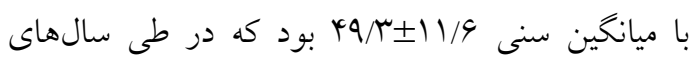

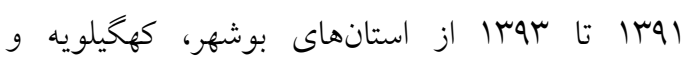
بويراحمد، هرمزكان و اهواز به بيمارستانهاى شهيد فقيهى و نمازى شيراز مراجعه نموده و ابتلاى به سرطان



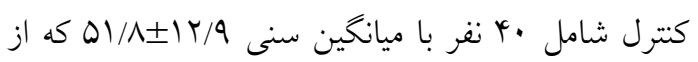

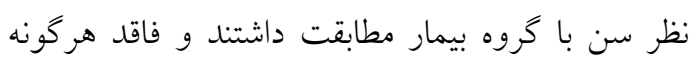

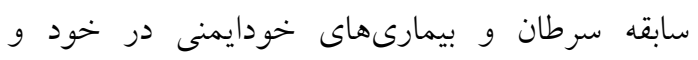

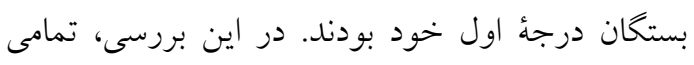

9 Forward primer: 5-AACAAGTAAGAATGAAAAGAGGACATGGT-3

Reverse primer: 5-CCCCCAATGAGGTCATAGAAGAATC-3

$$
\text { و جهت موقعيت IL-17F A7488G از يرايمرهاى }
$$

Forward primer: 5-ACCAAGGCTGCTCTGTTTCT-3

Reverse primer: 5-GGTAAGGAGTGGCATTTCTA-3

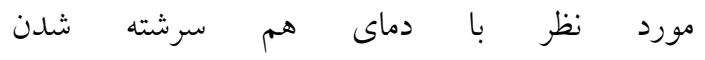
برابر 90 درجه سانتى گر اد

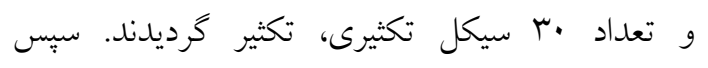
محصولات PCR به ترتيب تحت تأثير آنزيمهاى

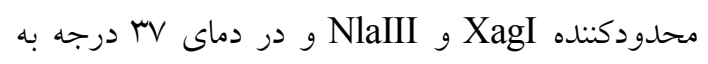
مدت 19 ساعت قرار كرفتند. محصولات حاصل از

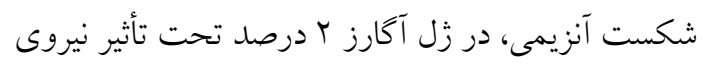

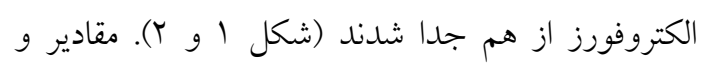

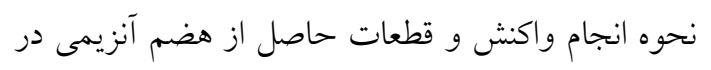

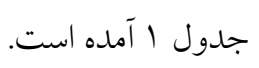

استفاده گرديد. براى انجام واكنش PCR براى هر دو موقعيت به هر تيوب //1/ ميكروليتر آب، آ ميكروليتر

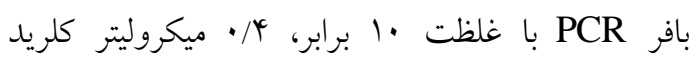

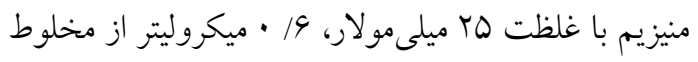

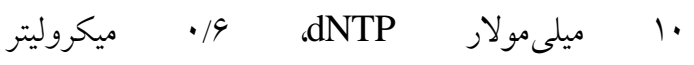

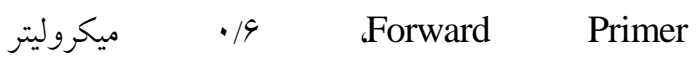
Reverse Primer

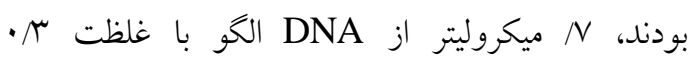

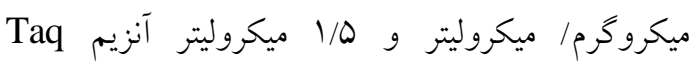
بلى مراز با غلظت ا واحد بر ميكروليتر افزوده شد.

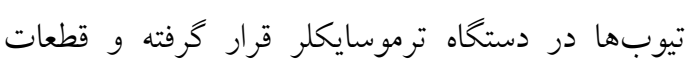




\begin{tabular}{|c|c|c|c|c|}
\hline بلى نوكورفيسم تكى & سرشته شدن هم & كنزئ & جايكاه شناسايى & قطعات حاصل از شكست \\
\hline $\begin{array}{c}\text { IL-17A } \\
\text { rstrvQ9IrG197A }\end{array}$ & 90 & XagI & $\begin{array}{c}5^{\prime} \mathrm{CCTNN} \downarrow N N N A G G . . .3^{\prime} \\
3^{\prime} \text { GGANNN } \uparrow N N T C C . .5^{\prime}\end{array}$ & 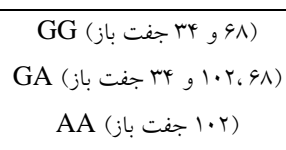 \\
\hline $\begin{array}{l}\text { IL-17F A7488G } \\
\text { rsV9YVA. }\end{array}$ & 90 & NlaIII & $\begin{array}{c}5^{\prime} \ldots \text { CATG } \downarrow \ldots 3^{\prime} \\
3^{\prime} \ldots \uparrow \mathrm{GTAC} \ldots 5^{\prime}\end{array}$ & 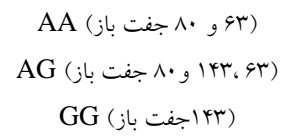 \\
\hline
\end{tabular}

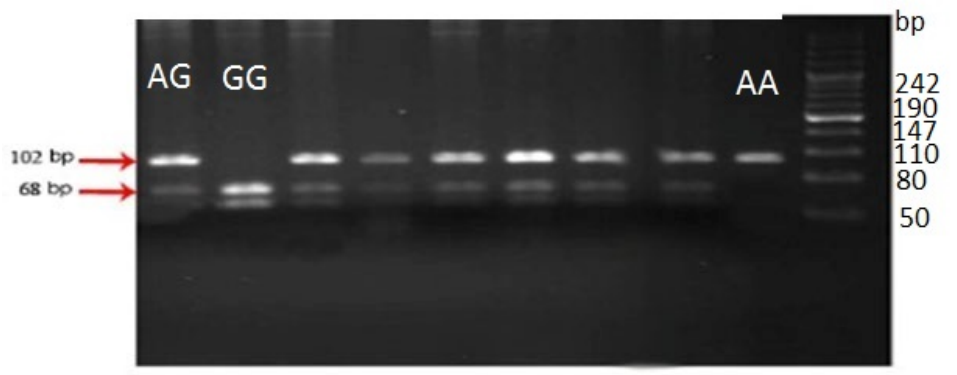

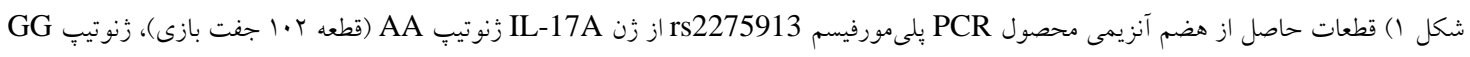

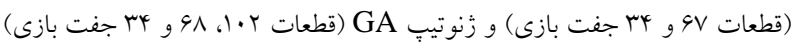

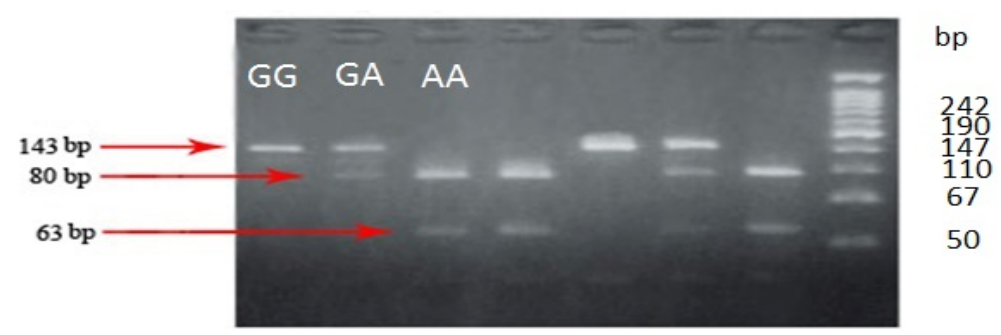

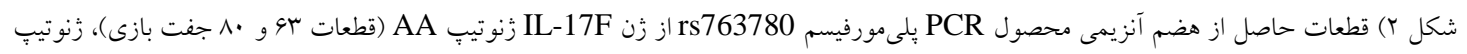

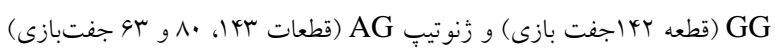

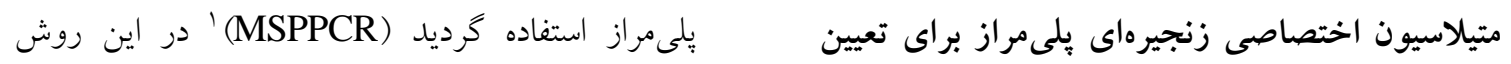

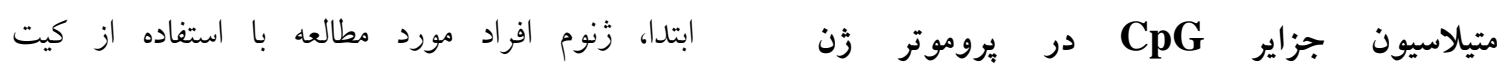

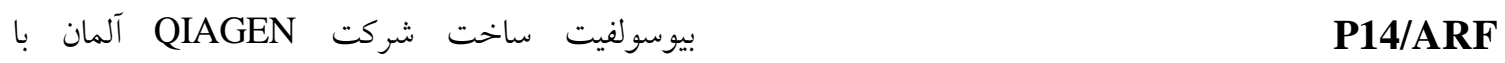

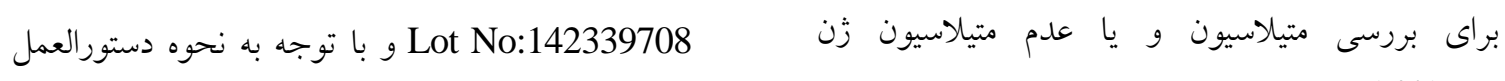
P14/ARF از روش متيلاسيون اختصاصى زنجيرهاى بونيون

${ }^{1}$ Methylation specific PCR

http://bpums.ac.ir 
اختصاصى آنها متفاوت بود. روش كار بهطور خلاصه به

اين صورت بود كه براى هر دو موقعيت به هر تيوب

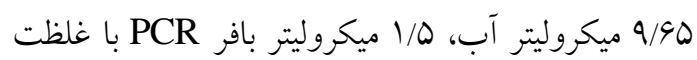

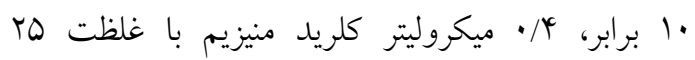
ميلى مولار، ه广\&/ • هأميكروليتر از مخلوط •ا ميلى مولار

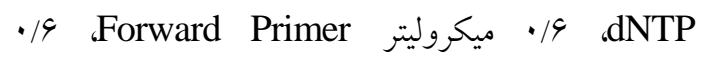
ميكروليتر Reverse Primer كه يرايمرها با غلظت (· مئر بيكومولار) بودند، ا ميكروليتر از DNA الخو با غلظت Taq ميكروگرم/ ميكروليتر ب ميكروليتر آنزيم يلى مراز با غلظت | واحد بر ميكروليتر افزوده شد. تيوبها در دستخاه ترموسايكلر قرار گرفته و قطعات

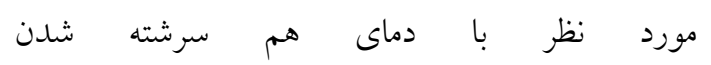
برابر OV/I براى بررسى (annealing temperature) متيلاسيون و 0/ درجه سانتى گراد براى بررسى عدم متيلاسيون و تعداد سب سيكل تكثيرى، تكثير كرديدند. بّ از يايان واكنش MSPCR، محصولات در زل آكارز r درصد، الكتروفورز شد. توالى ثيرايمرهاى استفاده شده

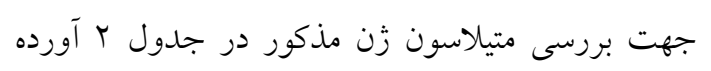

كيت، آمادهسازى كرديد كه در انتها، اين اعمال باعث مىشدند كه بازهاى آلى سيتوزينى كه متيله شده، دست

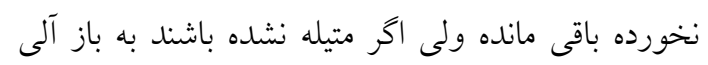

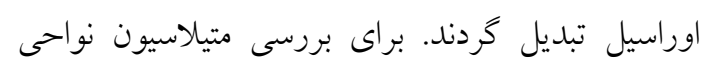

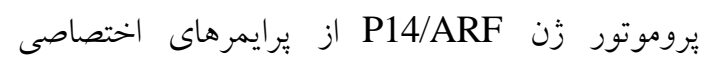
استفاده شد. لازم به ذكر است كه براى هر زن نياز به دو زوج برايمر اختصاصى بود. يكى براى بررسى متيلاسيون

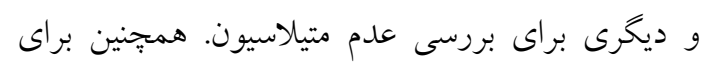
كتترل مثبت و منفى متيلاسيون واكنش هاى انجام شده از

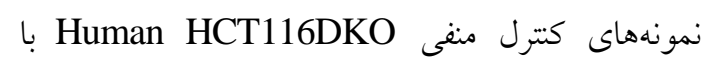

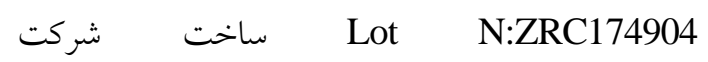
Zymoresearch كتترل مشبت HCT116DKO

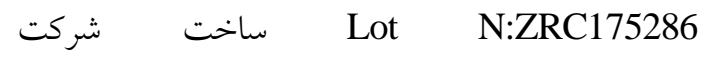
Zymoresearch براى هر نمونه نياز به دو تيوب جداگانه براى بررسى متيلاسيون و يا عدم متيلاسيون زنهاى مورد مطالعه براى هر فرد مىباشد كه محتويات و مقادير هر

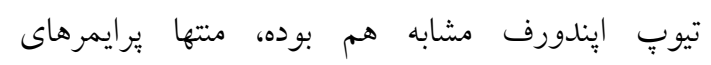

جدول r) برايمرهاى اختصاصى جهت واكنش MSPPCR زن P14/ARF (Y)

\begin{tabular}{lcc}
\hline GTGTTAAAGGGCGGCGTAGC & MF & p14 \\
AAAACCCTCACTCGCGACGA & MR & p14 \\
TTTTTGGTGTTAAAGGGTGGTGTAGT & UMF & p14 \\
CACAAAAACCCTCACTCACAACAA & UMR & p14 \\
\hline
\end{tabular}

CACAAAAACCCTCACTCACAACAA

UMR

Unmethylation Reversed

آزمسون آمـارى مربع كاى و برنامـه آرلى كويين

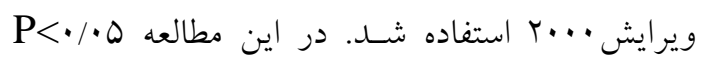

$$
\text { معنى مار تلقى شد. }
$$

\section{يافته ها}

نتايج حاصل از آزمايش MSPCR در مورد زن

P14/ARF

\section{اصول كاربرد آمار زيستى}

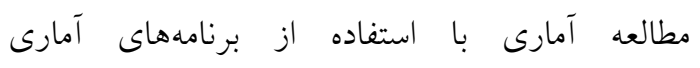

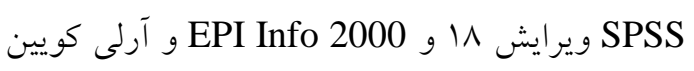

و با آزمونهاى مجذور كاى (x2) و فيشر بسته به مورد انجام كرفت. براى بروسى لونى اينكه

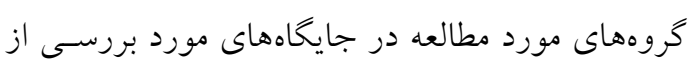

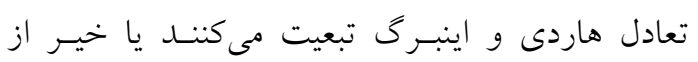


يروموتر متيله و غيرمتيله به صورت هتروزيكوت

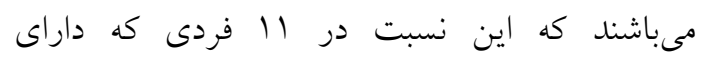

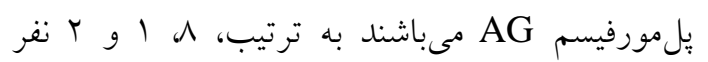

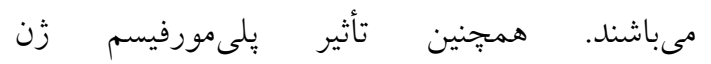

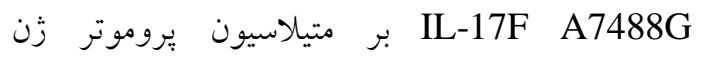

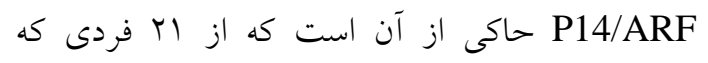

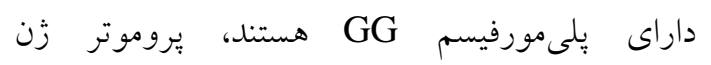
1. P14/ARF يروموتر غيرمتيله و ه نفر داراى يروموتر متيله و غيرمتيله به صورت هتروزيخوت مى باشند كه اين

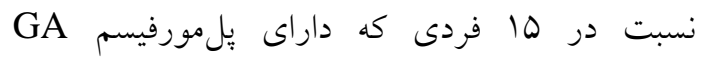

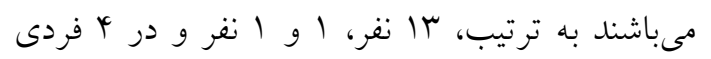

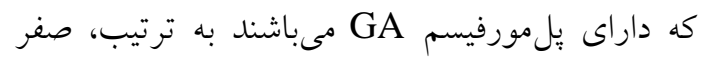

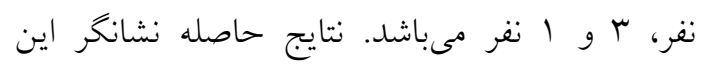
مطلب بود كه ميان يلى مورفيسمهاى ذكر شده با ميزان

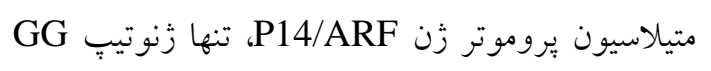
در يلىمورفيسم زن IL17 F با متيلاسيون يروموتر

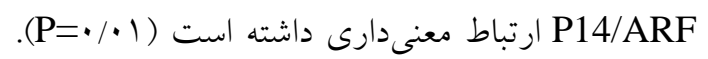

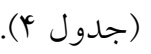

جدول F) بر رسى بلىمورفيسم زن IL-17A G197A بر

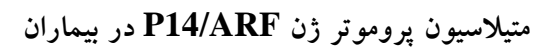

\begin{tabular}{|c|c|c|c|c|c|c|}
\hline \multirow{2}{*}{$\begin{array}{c}\mathbf{P} \\
\cdot / r\end{array}$} & \multicolumn{4}{|c|}{ P14/ARF } & & \\
\hline & كل & $\mathrm{M} / \mathrm{UM}$ & UM & M & & \\
\hline & rی & 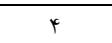 & 9 & 10 & $\mathrm{AA}$ & \multirow{3}{*}{ IL-17A } \\
\hline & 11 & r & 1 & $\wedge$ & AG & \\
\hline & r & 1. & 4 & ra & Total & \\
\hline$\% 1$ & r & 0 & 4 & 1. & GG & \multirow{4}{*}{ IL-17F } \\
\hline$\% \vee v$ & 10 & 1 & 1 & ir & GA & \\
\hline .1 .9 & r & 1 & r & . & AA & \\
\hline & rr & 1. & v & r. & Total & \\
\hline
\end{tabular}

سرطان پِّتان يكى از سرطانهاى شايع است كه

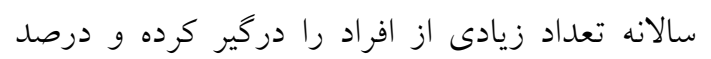

روشهاى آزمايش منجر به توليد محصولى به طول r I ا جفت باز به عنوان قطعه مورد آزمايش در مورد

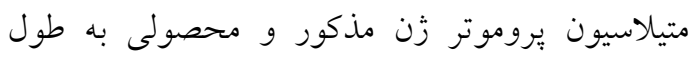

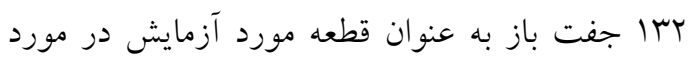
عدم متيلاسيون يروموتر زن P14/ARF شد. يروموتر زن P14/ARF افرادى كه فقط باند بrا جفت جنت بازى

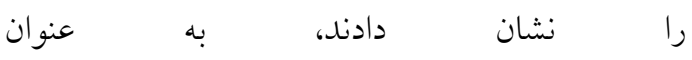
CIHM (CpG Island Hyper Methylation) محسوب شدند كه در اين افراد تعداد ץ يا بيشتر از ץ دى نوكلئوتيد CpG يروموترزن آنها دجار متيلاسيون شده و به عنوان CIHM محسوب مى شيوند. نتايج حاصله، مؤيد اين مطلب بود كه ميان متيلاسيون يروموتر زن P14/ARF و ايجاد بيمارى ارتباط معنى دارى وجود دارد بدين صورت كه عدم متيلاسيون

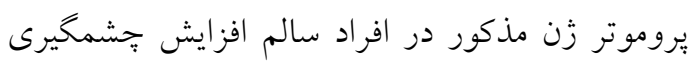

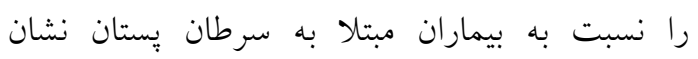

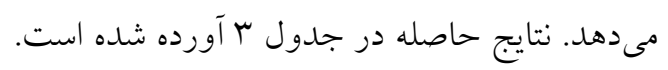

جدول r) مقايسه متيلاسيون بِروموتر زن P14/ARF

\begin{tabular}{|c|c|c|c|}
\hline \multirow{2}{*}{ P14/ARF } & \multicolumn{2}{|c|}{ افراد مورد مطالعه } & \multirow{2}{*}{$\mathbf{P v}$} \\
\hline & بيماران & گروه كنترل & \\
\hline M & $\ln (\% \varphi \theta)$ & $1 r(/ r \cdot)$ & $\cdot / 4$ \\
\hline UM & $1 \%(/ \% \Delta)$ & $r r(\% / \Delta V / \Delta)$ &.$/ 4$ \\
\hline M/UM & $\Lambda(\% / r \cdot)$ & $\Delta(\%, Y / \Delta)$ & $\cdot / r$ \\
\hline Total & r. & r. & \\
\hline
\end{tabular}

M: methylation; UM: UN methylation در ادامه تجزيه و تحليل اطلاعات، به بررسى تأثير


يروموتر زن P14/ARF استخراج شده از بيماران مبتلا

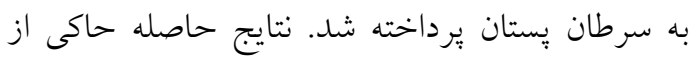

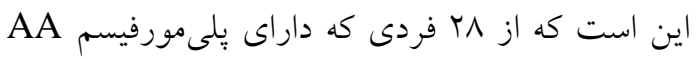
هستند، يُووموتر زن P14/ARF يانزده نفر از آنها متيله

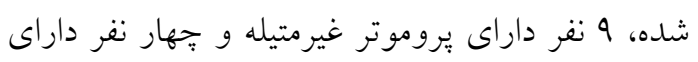


خون محيطى افراد مبتلا به سرطان يستان و افراد كنترل

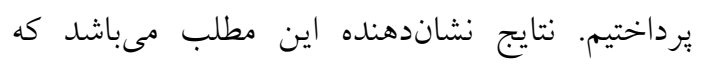

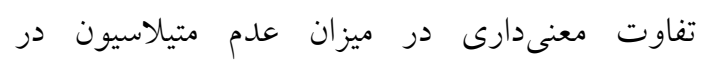
يروموتر زن مذكور در افراد سالم نسبت به افراد مبتلا

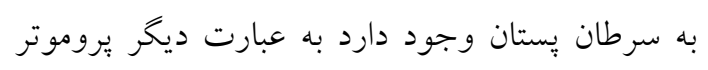

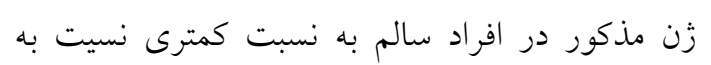

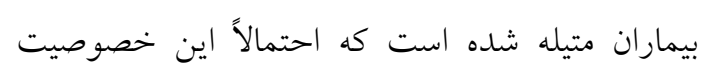

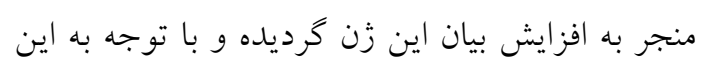

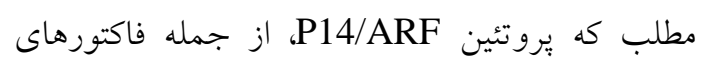

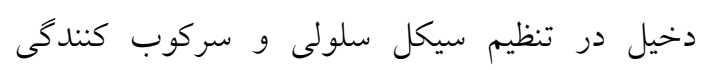

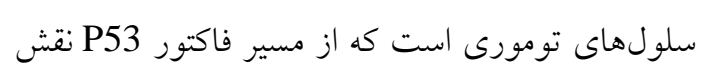
مهمى را ايفا مىنمايد، به نظر مىرسد كه متيلاسيون و

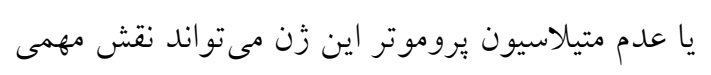

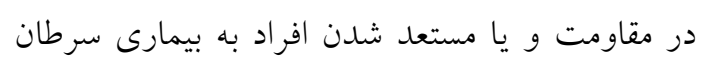

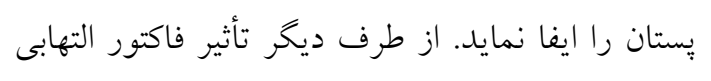

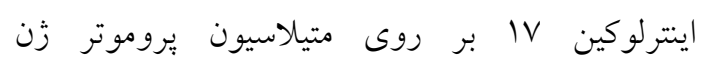

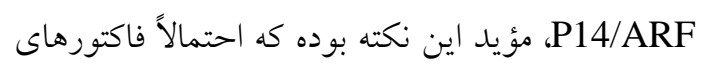

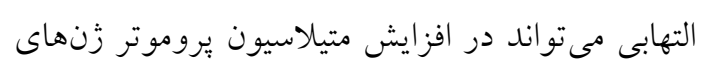
تنظيمى سيكل سلولى، نقش مؤثرى را ايفا نمايند.

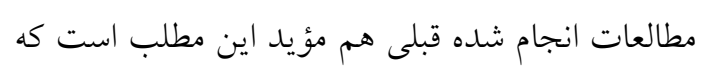

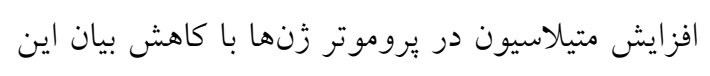

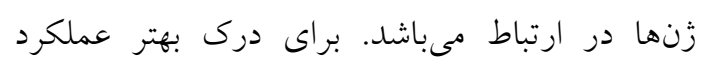
P14/ARF

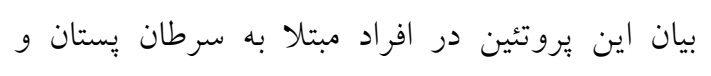
ميزان متيلاسيون زن مذكور يرداخت. مطالعاتى كه قبلاً

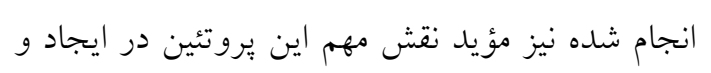

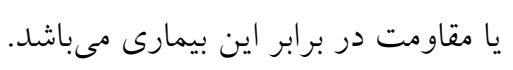
جيمز (James) و همكاران در تحقيقى كه با استفاده

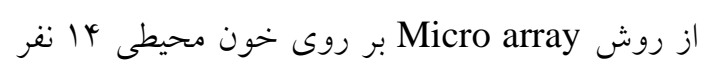

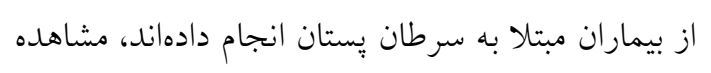

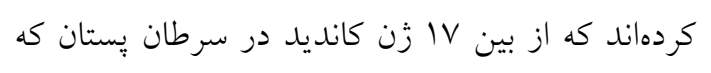

بالايى از افراد در اثر اين بيمارى جان خود را از دست

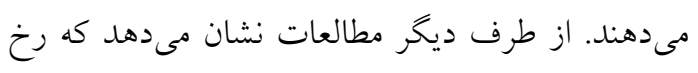

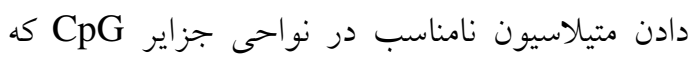
غيرمتيله مىباشند، منجر به ناميرا شدن و ترانسفورم

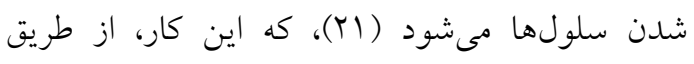
غيرفعال شدن نسخهبردارى زنهاى سركوب كننده

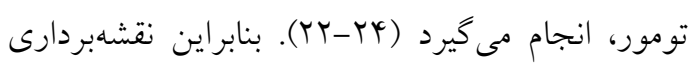

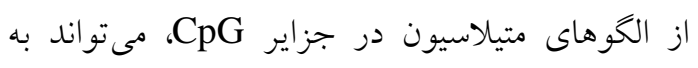

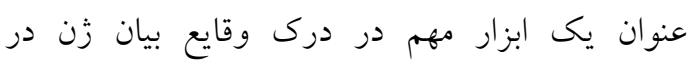

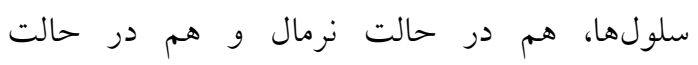
هياتولوزيكى (مثل سرطان) مورد استفاده قرار كيرد. همجنين، مطالعات انجام شده نشاندهنده اين موضورع مىباشد كه التهاب و ايجاد واكنشهاى اكسيداتيو در سلولها مىتواند منجر به افزايش متيلاسيون DNA

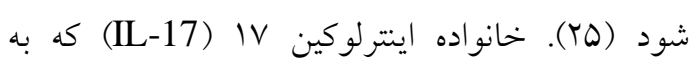
عنوان فاكتورهاى بيش التهابى عمل مىنمايند، شامل

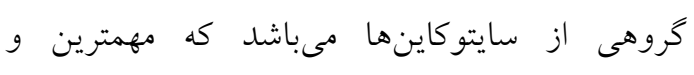

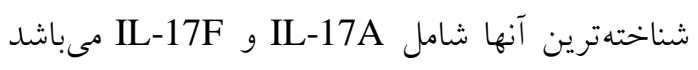

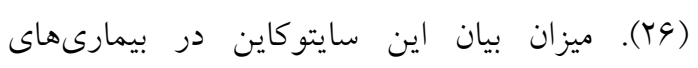
خودايمنى از قبيل روماتيسم مفصلى و يسورياسيس و ونئ

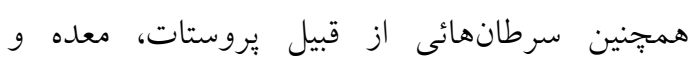

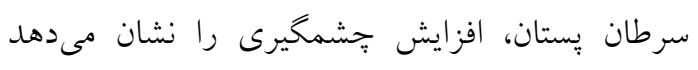

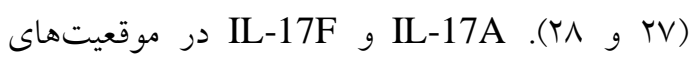
A7488G و G197A به ترتيب داراى يلى مورفيسم

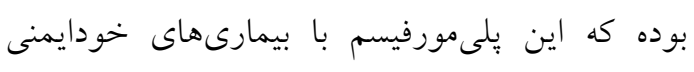

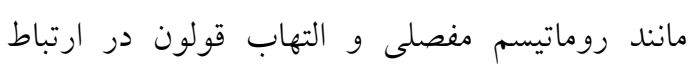

$$
\text { مىباشد (qو و م •r). }
$$
همجِنين مطالعات انجام شده حاكى از ارتباط اين

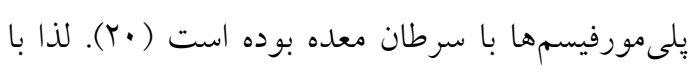

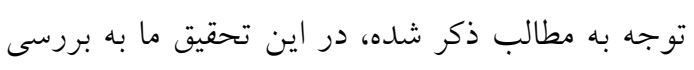

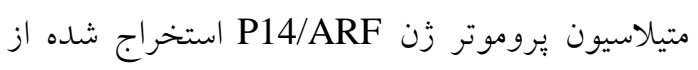


نقش مهارى اين فاكتور در جرخه سلولى را بهتر

نمايان مىسازد (ه)).

شولنينا (Shulenina) و همكاران به بررسى ميزان بيان P14/ARF و ديخر زنهاى دخيل در مسير تنظيمى

P53 در بيماران مبتلا به سرطان خون قبل و بعد از

راديودرمانى يرداخته و به اين نتيجه رسيدند كه كاهش

بيان اين زنها در بيماران مىتواند منجر به تغييرات

$$
\text { موتاسيونى كردد (צr). }
$$

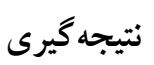

با توجه به مطالب ذكر شده و اطلاعات به دست آمله

و با عنايت به نقش مهارى يروتئين P14/ARF در

مهار سيكل سلولى و كنترل نمودن جرخه سلولى از

طريق مسير P53 به نظر مىرسد كه متيلاسيون و يا

عدم متيلاسيون زيروموتر زن P14/ARF با تأثير

ايىزنتيكى بر روى خاموش و يا روشن شدن شدن زن ئن

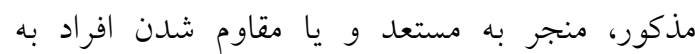

$$
\text { بيمارى سرطان يستان مى گردد. }
$$

تضاد منافع
در بررسى آنها مورد استفاده قرار كرفته، ميزان متيلاسيون ATM (يكى از زنهاى كانديد در ايجاد سرطان يُتان) با بيمارى ارتباط مستقيمى داشته و اين

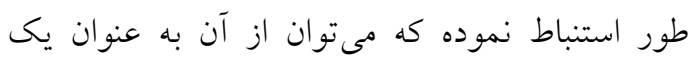
بيوماركر استفاده نمود (آ). عسكرى و همكاران در مطالعهاى كه بر روى بيماران مبتلا به سرطان يستان در كشور هندوستان انجام دادند، به اين نتيجه رسيدند كه افزايش متيلاسيون زنهاى P14/ARF و P16/Ink4 با بيمارى سرطان يستان در

ارتباط مىباشد (r) (Y).

اشميت (Schmitt) و همكاران، با آزمايش بر روى ليمفوماى موشى به اين نكته دست بيدا كردند كه موتاسيون در زنهاى P53 و INK4A/ARF باعث و مقاومت داروئى تومور مى مردد (سM). در مطالعه ديخرى كه توسط لينخى (Linggi) و همكاران انجام كرفت، به اين نتيجه رسيدند كه يك مهار كننده تومورى در بسيارى از P14/ARF لو كمياى انسانى مىباشد (Y). وازير (Wazir) و همكاران در مطالعهاى كه بر روى سرطان يستان انجام دادند به اين نتيجه رسيدند كه ميزان بيان mRNA P14 در نمونههاى غيرسرطانى بسيار بيشتر از نمونههاى بيمار مىباشد كه اين مطلب،

\section{References:}

1.Ting AH, McGarvey KM, Baylin SB. The cancer epigenome--components and functional correlates. Genes Dev 2006; 20(23): 3215-31.

2.Gerstung $\mathrm{M}$, Eriksson $\mathrm{N}$, Lin $\mathrm{J}$, et al. The temporal order of genetic and pathway alterations in tumorigenesis. PLoS One 2011; 6(11): e27136.

3.Widschwendter M, Jones PA. DNA methylation and breast carcinogenesis. Oncogene 2002; 21(35): 5462-82.

4.Polyak K. Breast cancer: origins and evolution. J Clin Invest 2007; 117(11): 3155-63.

5.Baylin SB, Ohm JE. Epigenetic gene silencing in cancer-a mechanism for early oncogenic pathway addiction. Nat Rev Cancer 2006; 6(2): 107-16.

6.Esteller M. Cancer epigenomics: DNA methylomes and histone-modification maps. Nat Rev Genet 2007; 8(4): 286-98.

7.Jones PA, Baylin SB. The fundamental role of epigenetic events in cancer. Nat Rev Genet 2002; 3(6): 415-28.

8.Jones PA, Baylin SB. The epigenomics of cancer. Cell. 2007 Feb 23;128(4):683-92.

9.Bird AP. DNA methylation and the frequency of $\mathrm{CpG}$ in animal DNA. Nucleic Acids Res 1980; 8(7): 1499-504. 
10.Bird AP. Gene number, noise reduction and biological complexity. Trends Genet 1995; 11(3): 94-100.

11.Vanyushin BF, Tkacheva SG, Belozersky AN. Rare bases in animal DNA. Nature 1970; 225(5236): 948-9.

12.Antequera F, Bird A. Number of CpG islands and genes in human and mouse. Proc Natl Acad Sci U S A 1993; 90(24): 11995-9.

13.Duro D, Bernard O, Della Valle V, et al. A new type of p16INK4/MTS1 gene transcript expressed in B-cell malignancies. Oncogene 1995; 11(1): 21-9.

14.Sharpless NE. INK4a/ARF: a multifunctional tumor suppressor locus. Mutat Res 2005; 576(1-2): 22-38.

15.Harland M, Taylor CF, Chambers PA, et al. A mutation hotspot at the p14ARF splice site. Oncogene 2005; 24(28): 4604-8.

16.Hizawa N, Kawaguchi M, Huang SK, et al. Role of interleukin-17F in chronic inflammatory and allergic lung disease. Clin Exp Allergy 2006; 36(9): 1109-14.

17.Park H, Li Z, Yang XO, et al. A distinct lineage of CD4 $\mathrm{T}$ cells regulates tissue inflammation by producing interleukin 17 . Nat Immunol 2005; 6(11): 1133-41.

18.Yang XO, Chang SH, Park $\mathrm{H}$, et al. Regulation of inflammatory responses by IL17F. J Exp Med 2008; 205(5): 1063-75.

19.Fossiez F, Djossou O, Chomarat P, et al. T cell interleukin-17 induces stromal cells to produce proinflammatory and hematopoietic cytokines. J Exp Med 1996; 183(6): 2593-603.

20.Wu X, Zeng Z, Chen B, et al. Association between polymorphisms in interleukin-17A and interleukin-17F genes and risks of gastric cancer. Int J Cancer 2010; 127(1): 86-92.

21.Tahara T, Shibata T, Nakamura M, et al. Effect of polymorphisms of IL-17A, $-17 \mathrm{~F}$ and MIF genes on CpG island hyper-methylation (CIHM) in the human gastric mucosa. Int $\mathrm{J}$ Mol Med 2009; 24(4): 563-9.

22.Herman JG, Latif F, Weng Y, et al. Silencing of the VHL tumor-suppressor gene by DNA methylation in renal carcinoma. Proc Natl Acad Sci U S A 1994; 91(21): 9700-4.

23.Herman JG, Merlo A, Mao L, et al. Inactivation of the CDKN2/p16/MTS1 gene is frequently associated with aberrant DNA methylation in all common human cancers. Cancer Res 1995; 55(20): 4525-30.

24.Herman JG, Jen J, Merlo A, et al. Hypermethylation-associated inactivation indicates a tumor suppressor role for p15INK4B. Cancer Res 1996; 56(4): 722-7.

25.Issa JP. CpG-island methylation in aging and cancer. Curr Top Microbiol Immunol 2000; 249: 101-18.

26.Kawaguchi M, Adachi M, Oda N, et al. IL-17 cytokine family. J Allergy Clin Immunol 2004; 114(6): 1265-73.

27.Chang SH, Dong C. A novel heterodimeric cytokine consisting of IL-17 and IL-17F regulates inflammatory responses. Cell Res 2007; 17(5): 435-40.

28.Chang SH, Dong C. IL-17F: regulation, signaling and function in inflammation. Cytokine 2009; 46(1): 7-11.

29.Nordang GB, Viken MK, Hollis-Moffatt JE, et al. Association analysis of the interleukin 17A gene in Caucasian rheumatoid arthritis patients from Norway and New Zealand. Rheumatology (Oxford) 2009; 48(4): 367-70.

30.Arisawa T, Tahara T, Shibata $\mathrm{T}$, et al. The influence of polymorphisms of interleukin17A and interleukin-17F genes on the susceptibility to ulcerative colitis. J Clin Immunol 2008; 28(1): 44-9.

31.Flanagan JM, Munoz-Alegre M, Henderson $\mathrm{S}$, et al. Gene-body hypermethylation of ATM in peripheral blood DNA of bilateral breast cancer patients. Hum Mol Genet 2009; 18(7): 1332-42.

32.Askari M, Sobti RC, Nikbakht M, et al. Promoter hypermethylation of tumour suppressor genes (p14/ARF and p16/INK4a): case-control study in North Indian population. Mol Biol Rep 2013; 40(8): 4921-8.

33.Schmitt CA, Fridman JS, Yang M, et al. A senescence program controlled by p53 and p16INK4a contributes to the outcome of cancer therapy. Cell 2002; 109(3): 335-46.

34.Linggi B, Muller-Tidow C, van de Locht L, et al. The $t(8 ; 21)$ fusion protein, AML1 ETO, specifically represses the transcription of the p14(ARF) tumor suppressor in acute myeloid leukemia. Nat Med 2002; 8(7): 743-50.

35.Wazir U, Jiang WG, Yasaei H, et al. P14ARF is down-regulated during tumour progression and predicts the clinical outcome in human breast cancer. Anticancer Res 2013; 33(5): 2185-9.

36.Shulenina LV, Ushenkova LN, Ledin EV, et al. Expression of P53, NPM1, Kras, c-Myc, p14(ARF) genes in blood cells of cancer patients before and after radiation therapy]. Radiats Biol Radioecol 2012; 52(6): 572-81. 


\title{
Study of P14/ARF Gene Promoter Methylation and Effect of Interleukin-17 Gene Polymorphism on this Methylation among Breast Cancer Patients
}

\author{
S. Naeimi $^{{ }^{*}}$ \\ ${ }^{1}$ Department of Genetics, Collegue of Science, Kazerun branch, Islamic Azad University, Kazerun, Iran
}

(Received 1 Jul, $2015 \quad$ Accepted 7 Dec, 2015)

\begin{abstract}
Background: hyper-methylation in CpG Island is one of the major mechanisms in gene silencing. In many cancers, different genes are experiencing CIHM (CpG island hyper methylation). P14 / ARF regulatory factor, involved in negative regulation of the cell cycle through the effect on P53 factor pathway. On the other hand, Interleukin 17 can be increased methylation by inflammatory effects. The purpose of this study was to study the P14/ARF gene promoter methylation and effect of Interleukin-17 on this methylation among breast cancer patients in the south of the country and its comparison with healthy people.

Materials and Methods: in this case-control study, peripheral blood of 40 patients with breast cancer who were referred to hospitals in Shiraz and 40 healthy women was used to DNA extraction by using salt out and $\mathrm{K}$ proteinase. Control subjects with a family history of cancer or autoimmune diseases were excluded from the study. We used PCR-RFLP method In order to study of Interleukin-17 gene polymorphism, and MSPCR method was used to study of P14/ARF gene promoter methylation. The results of the study were studied by using SPSS software, Arlequin, chi-square and Hardy-weinberg equilibrium test was used respectively.

Results: findings confirms that there was a significant association between P14/ARF gene promoter methylation and disease and mentioned gene promoter was less methylated in healthy subjects compared to patients $(\mathrm{p}<0.05)$. On the other hand, there is a significant association between GG genotype in IL17 F gene polymorphisms and $\mathrm{P} 14$ /ARF gene methylation $(\mathrm{P}<0.05)$.

Conclusion: P14/ARF gene promoter's methylation play an important role in breast cancer. Due to the decline of P14P14/ARF gene promoters methylation and its association with this disease, seems that it could be used as a biomarker for diagnosis.
\end{abstract}

Key word: Breast cancer, promoter methylation, polymorphism, Interleukin-17, P14/ARF

CIran South Med J. All rights reserved.

Cite this article as: Naeimi S. Study of P14/ARF Gene Promoter Methylation and Effect of Interleukin-17 Gene Polymorphism on This Methylation among Breast Cancer Patients. Iran South Med J 2016; 19(5): 809-818.

Copyright ( 2016 Naeimi. This is an open-access article distributed under the terms of the Creative Commons Attribution-noncommercial 4.0 International License which permits copy and redistribute the material just in noncommercial usages, provided the original work is properly cited.

*Address for correspondence: Department of Genetics, Collegue of Science, Kazerun branch, Islamic Azad University, Kazerun, Iran. Email: naeimis@kau.ac.ir

Website: http://bpums.ac.ir Journal Address: http://ismj.bpums.ac.ir 